Published summer 6, 2, 2011 Journal of Body, Movement and Dance in

\title{
Psychotherapy
}

\section{Languaging the Embodied Experience}

\section{Heidrun Panhofer and Helen Payne}

\section{HEIDRUN PANHOFER}

Heidrun Panhofer, PhD, MA DMT, senior registered member DMT of the Spanish Dance Movement Therapy Association, is coordinator and lecturer of the Master and Postgraduate Programme of Dance Movement Therapy at the Department of Psychology, Universitat Autònoma de Barcelona, Spain. Originally Austrian, she edited the first book on Dance Movement Therapy in Spanish "El cuerpo en psicoterapia: La teoría y práctica de la Danza Movimiento Terapia" (The body in psychotherapy Theory and practice of Dance Movement Therapy). As a co-founder she served as the president of the Spanish Association for Dance Movement Therapy, ADMTE for four years. She lectures in DMT at different universities and institutes in Europe and her clinical practice includes group and individual work with children, adolescents and adults in special educational institutions, different psychiatric settings and private practice in the UK, Germany and Spain.

Universitat Autònoma de Barcelona, Màster en DMT, Edifici d'estudiants, 08193 Bellaterra, España.

Telf. 0034 -615 346657 Mail: info@en-e-mocion.com

\section{HELEN PAYNE}

Professor Helen Payne, $\mathrm{PhD}$, is a researcher, trainer and supervisor at the University of Hertfordshire leading the 'Arts, Counselling and Psychotherapy Research Group'. She is a UKCP accredited psychotherapist, Fellow of, and Senior Registered movement psychotherapist with, ADMT UK and a Group Analyst. Research and clinical practice has been concerned with DMT and children with autism, learning disability and emotional disturbance, young offenders, personal development groups for trainees and patients suffering medically unexplained symptoms,/anxiety/depression in primary care. She has written a number of articles and publications including Creative movement and dance in groupwork; Dance Movement Therapy: Theory and practice; A handbook of inquiry in the arts therapies; Dance Movement Therapy: Theory, research and practice; and Dance Movement Psychotherapy Supervision. She is founding editor-in-chief for the international journal Body, movement and dance in psychotherapy published by Taylor and Francis. Her clinical work has influenced her approach to Authentic Movement which is also informed by her extensive research. She trained in Laban Dance, Person-Centered Counselling and Group Analysis and has been developing her own form of Authentic Movement with groups and individuals for 25 years. She has a small private practice in group, individual and supervision work. 00441763288592

University of Hertfordshire, School of Psychology, Meridian House, 32 The Common, Hatfield, Herts AL10 0NZ, UK. 00441707285861 H.L.Payne@ herts.ac.uk 


\title{
Languaging the Embodied Experience
}

\author{
Heidrun Panhofer and Helen Payne
}

\section{$\underline{\text { Abstract }}$}

This article is based on a study (Panhofer, 2009) which explored ways of verbalizing the embodied experience and inquired into the essentially subjective undertaking of yielding meaning in the movement. In Dance Movement Psychotherapy (DMP), movement observation and analysis generally serves as a tool to understand, classify and interpret human movement, providing practitioners with a language for how to speak and describe movement. The study drew attention to the possibilities and limitations of wording the embodied experience, or, as Sheets-Johnstone (2007, p.1) referred to it as ' the challenge of languaging the experience'. Underlining nonlanguaged ways of knowing the study showed how movement replaces words in many ways and illustrated valuable possible methods of communicating the embodied experience such as the use of metaphors, images and poetry. It is suggested, as a result of the study, that the embodied word needs to be linked to a personal, emotive vocabulary rather than any technical movement observational language when practitioners communicate their practice to others.

\section{$\underline{\text { Key words }}$}

Dance Movement Psychotherapy, the embodied word, narrative, movement observation and analysis, therapeutic process. 


\section{Introduction}

Essential tools in Dance Movement Psychotherapy (DMP) are to mirror, synchronize, amplify and interact with the client's movement material not solely in movement but also in words. Just like a mirror and narrator, the therapist aims to help a client to find words for their embodied experience, kinaesthetic perception, emotional response or train of thought.

To capture and understand the movement response widespread methods of movement observation and analysis have been developed. Rossberg-Gempton and Poole (1992) describe the early interest of movement observation and analysis, going back as far as Darwin, James, Reich and Deutsch. According to Daly (1988) the field of movement observation can be divided into two: the nonverbal behaviour research which focuses mainly on the actions and structure of everyday life and emerged out of the work of sociology, psychology and anthropology in the late 1960s and 1970s, and the different systems of observation and analysis of movement such as Laban Movement Analysis (LMA) and the Kestenberg Movement Profile (KMP), enhanced by psychoanalytic thinking (Daly, 1988).

In DMP, movement observation and analysis generally is seen to serve as a very essential tool to understand, classify and interpret human movement (Davis \& Markus, 2006; Goodill, 2006; Levy, 1988; Moore \& Yamamoto, 2002; North, 1990; Panhofer, 2005; Payne, 1990, 1992; Rossberg-Gempton \& Poole 1992; Willke, Hölter \& Petzhold, 1999). Its techniques give the DMP practitioners a language for analysis and for how they speak about movement, and therefore a vocabulary to describe it. However, over 
the years, the authors recognized certain limitations in this vocabulary, for example students who stuck to their personal vocabulary instead of using the technical language, or had a hard time identifying the chosen technical vocabulary for their embodied experience. Certainly difficulties arose when sharing with other health professionals who were not familiar with the same vocabulary. Having worked in different European countries and in several multidisciplinary teams the first author became aware of the need to re-translate or re-explain the technical terms every time and started wondering about this process. Through her work as a lecturer and therapist she noticed that the embodied experience went hand in hand with a deeply rooted, personal language and thus felt the need to investigate the subjective embodied experience and the extent to which it could actually be put into words. This study therefore examined the extent to which the embodied experience can be worded and looked at possible ways of "languaging" the embodied experience-in ways other than LMA/KMP in order to eommunicate more effectively for the purpose of communication with others.

\section{The procedures of the threefold methodology structure}

The study used a mixed methodological strategy, drawing on different strands such as qualitative and quantitative approaches and using methodologies from diverse disciplines in order to achieve the most reliable findings. To a large extent however, the study was embedded into the qualitative paradigm which has been claimed to be particularly helpful to studying and enhancing clinical practice (Bordeaux-Silverstein, Carl, Auerbach \& -Leacant, 2006; Elliott \& Williams, 2001; Green \& Britten, 1998; Meekums \& Payne, 1993; Miller \& Crabtree, 2003). 
Artistic research methods (Hannula, 2004; McNiff, 1986, 1992, 1993, 1998; Nevanlinna, 2004; Wadsworth, 2000) such as movement and dance as a method of inquiry (Csordas, 1993; Koltai, 1994; Riley, 2004; Smith, 2002) and writing as a form of analysis (Coffey \& Atkinson, 1996; Reason \& Hawkins, 1988; Sparkes, 2002, 2003; Wolcott, 1994, 2001) were also employed, leading to a threefold process which shifted between the written word, movement and again the written word.

One aspect of the data collection-data collection procedure consisted of a one-day workshop $^{1}$ and focus group with the participating co researchers $(\mathrm{CoRs})^{2}$. They were asked to write about a significant moment ${ }^{3}$ from their clinical practice, narrating in any desired form a particular moment where they had felt touched, reached some kind of insight, moved forward, etc. Subsequently, they were invited to create a movement sequence from their narrative, to experiment through improvisation and play in movement, what this moment had meant for them. Finally, they were asked for a written response to their movement experience, putting on paper a concluding narrative. After the workshop a focus group was conducted with all CoRs. This helped to evaluate the initial outcomes of the study and to explore the CoRs' personal views on how they worded the embodied experience.

The analysis of the data also included qualitative and linguistic frameworks of evaluation (Labov, 1972; Toolan, 2005; Wolcott, 1994, 2001). For a full description of the methodological procedures please see Panhofer (2009), Panhofer et al (2011a) and

\footnotetext{
${ }^{1}$ All co researchers have received complete information about the research project and have signed the informed consent prior to participating.

${ }^{2}$ The term 'co researcher' is a more recent development used mainly in collaborative and action-oriented studies. Quite common within the narrative tradition a co researcher is defined as "... a participant who collaborates with an investigator to better understand a subject" (Elfers, 2009) in order to explore their own practice in a cycle of action, reflection and generalisation which helps to modify their own working environments (Glennie \& Cosier, 1994).
} 
Panhofer et al (2011b). The findings of this research belong to a larger project and cannot be presented here at length due to wordage. However, some outcomes have been chosen for this article.

\section{Findings:}

A significant decrease in the use of words after the movement process became apparent, despite the same duration to complete the writing, as well as a certain change in the character of the writing following the movement. Furthermore, the reduced or lack of use of technical movement observational language was remarkable. These three findings are described and discussed in turn herewith.

3.1. Narratives diminish after movement (movement replaces words):

Comparing the initial narratives which were written before with those which were written after the movement process- each with the same time duration with the same time duration, a significant decrease in length could be noted. In the final narratives no lengthy descriptions remained as if the movement had replaced the words. "Words do not have so much strength, for me the embodied experience said it all," one of the CoRs confirmed. "The more movement sequences passed, the less I felt the need to write," said another.

\subsubsection{Nonlanguaged ways of knowing}

Even though Damasio (1999, p.185) calls human beings "languaged creatures" he also mentions our nonverbal, imaged narratives and questions if consciousness only occurs when language is present. That being the case, nonlanguaged animals or human babies would be just unlucky and unconscious forever: 
Words and sentences translate concepts, and concepts consist of the nonlanguaged idea of what things, actions, events, and relationships are. Of necessity, concepts precede words and sentences in both the evolution of the species and the daily experience of each and every one of us (Damasio, 1999, p. 185).

Lakoff and Johnson (1999) confirm this view and present three foundational principles. For them, firstly, the mind is inherently embodied, secondly, thought is mostly unconscious and thirdly, abstract concepts are largely metaphorical. Knowing can therefore happen in the body, in an unconscious or preconscious way, and in a nonlanguaged, metaphorical manner.

The findings from this study support this idea: consciousness seems to have been enhanced through the moving process; however, written language has diminished. "I understand more about my client after the movement," said one (CoR in the focus group, "it is more difficult to understand the story line from the outside than from the inside". Another CoR added: "I know something more now, after the movement. It is a knowing of the context, of how this situation has actually been which I did not have before. (...) I can understand better now how my client actually felt".

When discussing the limitation of wording the embodied experience one CoR gave a clear example of a nonverbal intervention which worked without needing to be put into words. She spoke about a DMP group with elderly patients which she had been leading for a while. A particular lady, despite her initial vehement rejection of movement, eventually engaged in the group dynamics by slowly moving her hands and shoulders. The CoR/therapist picked up the client's gestures through mirroring, and the entire group tuned into the movement suggested by the initially resistant client herewith acknowledging and encouraging her participation. The example illustrates one of the 
many possibilities of nonverbal interventions in DMP, which, according to most of the CoRs, can be understood by others without further verbalisation.

Even where verbalisation is lacking or when we run out of words we may still remain attentive, as Sheets-Johnstone (2003) indicates. In these circumstances we remain conscious and "knowing". Consequently, embodied cognition theory proposes a knowledge which is unavailable to the introspective consciousness ${ }^{4}$.

\subsubsection{Knowledge from "behind the scene" (beyond introspective consciousness)}

'Embodied cognition' and the 'embodied mind' have recently been proposed by philosophy, believing that the nature of the human mind is largely determined by the form of the human body. Gallagher (2005) investigates the influence of the body on self consciousness, perception, language and social cognition, claiming that the body shapes the mind at a fundamental level, contributing to a prior kind of knowledge which is unavailable to introspective consciousness, a knowledge which remains "behind the scene" (Gallagher, 2005, p. 141).

From neuroscience, Damasio calls this knowledge from "behind the scene" our “nonverbal narrative of knowing” (Damasio, 1999, p. 186). This nonverbal narrative creates consciousness that, according to him, is the foundation of consciousness. Damasio states that he would find it unlikely that consciousness would depend on the impulses of verbal translation and on the unpredictable level of focused attention paid to that.

\footnotetext{
${ }^{4}$ The term introspective consciousness stems from Cassam's (1995, p. 315) notion of introspective awareness, "a form of awareness that serves as the basis for making first-person statements in which the first-person pronoun is used as subject". Gallagher (2005, p. 237) picks up this term to describe how the embodied cognition comes before this introspective consciousness, "before you know it", as he states.
} 
Anttila (2007) uses the concept of Rauhala, a Finnish psychiatrist and philosopher who classifies organic, biological processes as "mindless" or absolutely non conscious and non symbolic. These processes, for example the dividing of a cell or the production of a blood cell are organic processes that cannot be experienced. They differ from the psychoanalytical definition of the unconscious referring to mental processes of which the subject is unaware (Rycroft, 1995). "Mindful" processes are those that can be experienced, according to Rauhala (2005 cited in Anttila 2007), comprising "possibly conscious" and "conscious" processes. "Possibly conscious" processes are not yet conscious and include bodily sensations - quite similar to the psychoanalytic concept termed 'pre-linguistic'.

From psychoanalysis, Stern, during a roundtable on 'Dance, movement and bodies: Forays into the non-linguistic and the challenge of languaging experience' (SheetsJohnstone, 2007) refers to an implicit relational knowing, a bodily knowing of how to deal with others, which an infant acquires during its first years of life. He argues that language in many ways would be obstructive to this process.

In the field of psychiatry and philosophy Fuchs (2004, p. 3) claims "Bodily learning means to forget what we have learned or done explicitly and to let it sink into implicit, unconscious knowing”.

In addition, Fuchs (2001) describes clearly, from research with amnesic patients, how a full comprehension of the life-world may suffer without this nonverbal, tacit knowing. Both authors, Stern and Fuchs, do not speak about an untouchable source of knowing but rather a rich storage which is there to be used and discovered. 
The process of moving brings the therapist and client in touch with this corporeal source of knowing or body memory. It is for that reason, not unsurprisingly, that the narratives in this study diminished after the movement.

\subsection{Limited technical language is employed by DMP practitioners}

In their narratives the CoRs referred very little to the use of specific movement observation and analysis language: Despite the fact that $87 \%$ of the narratives described movement, only $13 \%$ of the CoRs used LMA or KMP vocabulary for its description. Given that all CoRs were professional DMP practitioners with a fundamental background in LMA/movement observation, this percentage seemed rather small. Nonetheless, the number of CoRs was only seven and thus not enough for any generalisation to be made. Future research could investigate the helpfulness, or otherwise, of using this technical language by professional DMP practitioners to communicate their practice in a variety of contexts, for example with health colleagues, clients and supervisors.

However, the finding above allows for the speculation that the technical vocabulary, just like any sub-set of language, meets certain limitations when communicating the embodied experience. Most CoRs stated that they rarely used technical vocabulary in their clinical practice, especially with clients since its use seemed to surprise or even frighten them. Unfamiliar or unknown to them, it has a tendency to alienate rather than elucidate. 
One CoR mentioned that for her the technical language seemed to serve as a personal tool, allowing her to reflect on the client's themes, integrating what occurred during the therapy process and using this in preparing for future sessions. Instead of using the technical wordage with clients, supervisors or colleagues she found herself searching for her own words in order to describe the movement, and thus developed her own style of communicating the embodied experience, with a language quite different from the technical vocabulary.

\subsubsection{The limitations of technical language}

Laban, as reported in North (1990), distanced himself from the idea of an existing body language and did not claim that all embodied experience could be verbalized:

Movement is in both of its aspects not a language, but a building process in which many and varying operations and actions are compounded. Language, on the contrary, is a means of depicting things and ideas and to bring them in various degrees of clarity into consciousness. One can for the sake of understanding depict also movement, or at least its characteristics (North, 1990, p. 9).

This modest view draws attention to the limitation of what can be worded, and instead sheds a light on the supportive function of the analytical systems. They seem to help to depict movement characteristics and broaden the capacity to portray what happens in the body, without saying or knowing it all. Their value can also be considered from a more metaphorical point of view, rather than considering them as an efficient tool to describe and interpret movement in an objective manner (Kaylo, 2009). The claim of Bender and Birner therefore needs to be critically reconsidered when they state that the KMP for example serves:

...to interpret interpersonal dynamics in families, to recognize movement developments and preferences of personas and allows therefore for interpretations concerning needs, affect regulation, coping strategies, cognitive 
learning styles, defence mechanisms and social competences (Bender and Birner, 2007, p.55 $5^{5}$

Given that so little of the embodied experience can be worded the technical languages in DMP needs to be revised in terms of the extent to which it is really capable of such detailed capturing of the movement, and whether its claim for a thorough interpretation of all movement is justified. Further consideration must also be given to the fact that the complex vocabulary of the KMP or the LMA may only serve a small group of practitioners with their own sub-cultural context.

When speaking about LMA terminology North (1990, p. 4) points out that "the word makes sense only if the movement is experienced and recognised". For other health professionals neither the KMP nor LMA vocabulary has been bodily experienced beforehand and therefore the movement itself will not be recognised, as North suggests. It simply does not make sense to them and instead of providing a more profound and extensive so-called scientific language of movement, its use may, at best, be confusing and bewildering to our colleagues in health, social and educational settings.

The challenge of wording and communicating the embodied experience has long been examined by philosophy. The Austrian-English philosopher Wittgenstein $(1889-1951)$ challenged in his early oeuvre Tractatus Logico - Philosophicus (1922) the limits of language. When searching for a publisher for this book he wrote to the editor Ludwig von Ficker in 1919:

I once wanted to give a few words in the foreword which now actually are not in it, which, however, I'll write to you now because they might be a key for you: I wanted to write that my work consists of two parts: of the one which is here, and

\footnotetext{
5 Translation from German by Heidrun Panhofer.
} 
of everything which I have not written. And precisely this second part is the important one (Wittgenstein 1922, p. $133^{6}$ ).

In his late work Philosophical Investigations Wittgenstein (1953) deals largely with the difficulties of language and meaning. He compares language with an old town that has grown over time with its lanes and squares, new and old buildings from different époques, surrounded by different suburbs with their straight and linear streets (Wittgenstein, 1953, §18). The meaning of language to him is a complicated phenomenon that is woven into the fabric of our lives; it is rather a social event which happens between the users of language. With his concept of "language games" Wittgenstein $(1953, \S 7)$ alludes to the analogy between using language and playing a game according to certain rules. Words by themselves have no certain meaning, for example outside the 'language game' there is no meaning.

These common rules for a shared language seem to be of great importance for the application of KMP and LMA. Whereas DMP practitioners have been taught a certain set of rules concerning their specific technical vocabulary, their colleagues have not, and cannot therefore participate in the same "language game". For fellow health professionals the proposed technical words have no meaning. Using Wittgenstein's (1953, § 18) above-mentioned image of language being an old town that has grown over time, it seems as if colleagues, without previous DMP training, live in very different parts of the town, perhaps even country, feeling "at home" in lanes and squares with other shapes and functions. A DMP practitioner using technical language obliges them to visit her/his parts of the town rather than making her/his way out to their familiar territory.

\footnotetext{
6 Translation from German by Heidrun Panhofer.
} 
Given the modest use of technical vocabulary by the CoRs it appears however, that not even professional DMPs "living in the same part of town" apply the taught rules, or play the same "language game" when describing the embodied experience to themselves or each other. Instead, they draw on a personal, emotive vocabulary which seems to stem from earlier experiences than from their professional training, or they reduce words to a minimum, allowing the embodied experience to remain in the body.

\subsubsection{Transcultural limitations of language}

Laban, as a synthesizer of experiences and theories of movement, resisted narrow definitions of movement and developed his philosophies of movement out of lived experiences. Just like Merleau-Ponty he shared a commitment to "the things themselves," and to the body as the primary site of being and knowing (Connolly \& Lathrop, 1997, p. 42). North (1990, p. 4) adds: "There are no exact ready-made words," and describes how Laban had to find names appropriate to their content. He found the original words in German in the 1920s and 1930s. However, they were only translated into English after Laban's arrival in England in 1937, when he was almost 60 years of age.

Therefore not only the original selection of the vocabulary seems a delicate issue, but also its correct translation. For example, the Laban Library News notes problems during the translation process:

(...) trying to translate the verbal language used in the English version into Korean, and the possibility that maybe some of the English words should simply remain, with good, clear explanations in Korean of what they mean. After all, the English is often a translation from the original German! (Library News, 2007, p. 3) 
It seems a challenging issue to translate the specific Laban vocabulary from one language and culture to the other, confirming that 'there are no readymade words' which could work universally. This seems to be of vital importance considering that modern DMP practitioners work in many different contexts and environments (Dulicai \& Roskin Berger, 2005), encompassing numerous diverse sets of culture.

However, the most striking finding of the study affirms that the CoRs, although from different countries, all belonged to the same culture in the sense that they were all professional DMP practitioners and associated with the same national professional DMP association. Despite this they did not refer to the specific usage of technical language. According to the analysis of the final questionnaires following a period of practice using the proposed way of communicating the embodied experience of practice they confirmed having received extensive LMA and KMP instruction during their DMP training. Four CoRs trained at the same university in Barcelona (one of them both in Barcelona and in France), one studied in Holland, and one in the UK. All training programmes encompassed between 70 and 280 hours of movement observation and analysis, including LMA and KMP. Three CoRs also mentioned participating in further or previous short training courses in movement observation.

Nevertheless, their shared vocabulary did not manifest as an outcome in the study, as if despite their common training they did not play the same set of 'language games'. What seemed more important was the use of their private, emotive vocabulary, seemingly stemming from earlier experiences. This raises the question of whether a technical vocabulary learned in adulthood really serves to communicate the embodied experience, replacing a language that has been acquired in childhood. 
It is startling though that the technical language, according to the analysis of the CoRs' feedback, is used so infrequently in their professional life, at least when sharing with other professionals such as in case conferences. This fact may be connected with the inappropriateness of the vocabulary as discussed above, or -concerned perhaps with the lack of identity of a young profession such as DMP.

A typical characteristic of every science is its particular language, argues Hölter (2005) and its lack may indicate a particular early stage of the profession, still requiring its proper character and status with its unique roles in the 'language game.' It is suggested here that the introduction of LMA by the early pioneers may have been an attempt to give the profession a quasi "scientific" language in order to distinguish it, and perhaps shroud it in mystery - which is the function of many professional technical languages acting as a sort of gate-keeping function for membership to the emerging profession.

The findings also drew attention to the limitation of what in fact can be worded, placing the analytical systems in a supportive function which may help to depict movement characteristics and broaden the ability to describe what happens in the body, but within its proper limitations.

3.3 Emerging ways to communicate the embodied experience: metaphors and images Another finding showed a significant change in ways for communicating the embodied experience after the process of movement. Whereas the initial writings consisted mainly of linear descriptions with little personal involvement, the final narratives showed inner dialogues, rich in images and metaphors. Composed of rather short sentences that were 
more chaotic and expressive, these final narratives looked rather like poems with lines and verses. The use of metaphors and images in the narratives improved from an initial $77 \%$ to a final $93 \%$. One CoR stated in her final feedback: "I enjoyed experimenting with the poetry that appeared through the writing and the movement, something which seems to me, tells more than technical words or exact details of the situation."

Bracegirdle (2007) points out how poetry, as a representation in words and the interpretation of those words has been discussed for centuries. In her research she proposed clients record their experiences of sessions, using poetic forms of writing such as lines and stanzas, and herewith provided them with a containing structure. Her findings shed a light on how that which cannot be spoken can indeed be represented through the use of allegory, symbols and metaphor in words.

In this study (Panhofer, 2009) through the process of moving, words had been reduced but also become more concise, they had taken shape and gained containment through image and metaphor (Lago, 2004).

Metaphors have been documented as an important vehicle for awareness and change in psychotherapy. Gorelick (1989) even argues that metaphors are the driving agent that differentiates the Arts Therapies from other types of psychotherapy. DosamantesAlperson (1982) supports the notion that when clients convert their bodily experience into metaphoric language they create a language for bodily-felt experience that acts as a bridge to symbolic thought and verbal communication. Similarly, Meekums illustrates how movement metaphors facilitate "a complex interplay between the embodied experience and movement" (ibid, 2002, p. 25). 
Movement metaphors are essential for DMP as a form of nonverbal communication to supply important insights into a client's behaviour patterns, such as ways of thinking, relationships and emotional states, if examined closely. For example, lying down on the floor when "feeling low," allowing one's body "to be carried and supported" by someone else or by the group, "resisting" an external force, "flying high", ... all these may be moments shared in movement which may carry a deeper metaphorical meaning and are worth exploring as support for the therapeutic process in DMP. Samaritter (2007) underlines the importance of symbolising and connecting inner experience within the therapeutic process:

The embodied metaphors support the process of symbolising inner experiences as well as the process of connecting them through the danced relationship with the therapist to the outside world (Samaritter, 2007, p. 40).

For Ellis (2001) the movement metaphor is a kinaesthetic experience that bridges what she calls the "symbolic and knowing realms" (ibid, p. 182). Whereas the knowing realm is one of conscious knowing, the symbolic realm is a place of unconscious knowing, creativity and play. In the therapeutic process the therapist and client constantly shift between the symbolic and the knowing realms: sometimes the movement metaphor can stand there by itself needing no further clarification, at other times meaning will be given through conscious explanation or further verbalisation.

The concern of this study deals with the successful communication of profound inner experiences from one human being to another. Where verbal or technical language seems limited, the use of movement and metaphor offers new possibilities. Just as Lakoff and Johnson (2003, p. 5) talk about "experiencing one thing in terms of another" it becomes evident that if the embodied experience is the "one thing" words do not 
necessarily have to be the other. One may simply stick to the movement and use it as a metaphor to "carry over" the meaning. According to Lakoff and Johnson $(2003,1999)$, metaphors shape the sense of us as embodied beings, and this is the basis to understand all sorts of concepts. Gibbs, Lenz and Francozo (2004, p. 2) agree that "the poetic value and the communicative expressiveness of metaphoric language partly arises from its roots in people's ordinary, felt sensations of their bodies in action". Lakoff and Johnson defend a direct link between recurring patterns of embodied experience, metaphor, conventional and poetic language, agreeing with Gibbs.

Linguistic meaning is inherently embodied, not only in terms of where meaning comes from, but in regard to how people ordinarily use and understand language (Gibbs, 2003, p. 12).

Böger (2011) highlights the reciprocal connection between movement and meaning, illustrating that metaphors not only bridge an individual's inside world with the outside, but also work the other way round. In her experiment concerning metaphorical instructions she compares movement execution with and without the help of metaphors, demonstrating that the metaphorical instructions significantly improve motor execution.

Bracegirdle (2007) and Hunt and Sampson (2006) defend the connection between the body and the word, claiming that it is poetry which shifts the meaning and experience of text further into the physical world. In addition, Wilkins (2002) states that through metaphorical language invisible realities are engaged with, making them "visible". Both internal and external images make something that is abstract into something concrete, and something that is concrete into something that is abstract, just like the basic tenets of poetry. Wilkins (ibid) underlines that metaphorical language is the communication tool used by poetry therapy. 
This finding shows that a possible way of communicating the embodied experience from our clinical work in DMP to our health professional colleagues and supervisors, which may be more effective, is through the use of symbolic language using metaphors, images and poetry.

\section{Conclusions}

"We know more than we can tell" stated Polanyi (1967, p. 4), claiming that tacit knowledge cannot be put into words. The findings from this study confirm this view. Its methodological procedures, the shifting from writing to moving and back to writing, highlighted how the embodied experience often reduces the embodied word and draws attention to the limitations of using a technical analytical language to communicate the experience. Anttila (2007) presumes that most of our bodily sensations are preconscious until they become objects of our attention. The process of engaging in embodied perceptual practices has certainly stimulated the CoRs' consciousness, helping them to "tap into somatic images through all of our various sensory modalities" (Smith 2002, p. 133). The "felt sense" (Gendlin, 1996, p. 19) has enhanced the tacit, bodily knowing of the CoRs, even though this knowledge is not always translated into an implicit, verbal dimension but may remain in a symbolic, metaphoric realm (Allegranti, 2009).

It seems vital to consider this dimension because as Douglas and Moustakas (1985) state, without it the potential for new awareness and knowing is restricted. Putting the embodied experience into words seems to have its limitations since so much more seems to be stored in the body which cannot be worded in this way at all. However, this does not mean that the body is sacred and cannot be touched by the mind, an assumption which is quite frequent amongst dancers, according to an observation of 
Anttila (2008, personal communication). She warns that such a view may amplify the body/mind split as much as the discourse that considers the mind only as linguistic. For her, verbal translation allows for an extended consciousness and the expansion of the autobiographical self (Anttila, 2003).

The findings illustrate that more knowledge or insight has been reached through the process of moving, but without necessarily more verbalisation, as one CoR wrote in her final feedback: "Re-living the experience of the client in my own skin has given me new, clearer and more detailed information about what happens. It made it easier for me to understand and empathize with her".

A connection with bodily places of knowing has been established, a corporeal insight into the work with this particular client. The findings, in line with developments of cognitive linguistics (Gibbs \& Bogdonovich, 1999; Gibbs, 2003; Gibbs et al, 2004; Kövecses, 2003; Lakoff, 1987; Lakoff \& Johnson, 1999, 2003; Lakoff \& Turner, 1989) show that possible ways of communicating the embodied experience may be through a specific way of using words - metaphors, images and poetry. Consequently nonlanguaged ways of knowing need to be emphasised, placing the analytical systems in a supportive function to communication, and stressing crucially that, more than technical language, the embodied word needs to be linked to a personal, emotive vocabulary.

\section{References}

Anttila, E. (2007). Mind the Body. Unearthing the affiliation between the bonscious body and the reflective mind. In L Rouhiainen (Ed.), Ways of Knowing in Dance and Art. Yliopistopaino: Finnish Academy and the Arts Council of Finland. 
Anttila, E. (2003). A Dream Journey to the Unknown Searching for Dialogue in Dance Education. Helsinki: Theatre Academy Finland.

Allegranti, B (2009). Embodied performances of sexuality and gender: A feminist approach to dance movement psychotherapy and performance practice. International Journal of Body, Dance and Movement in Psychotherapy International Journal. 1, 4, 17 $-21$.

Bender, S. \& Birner, B. (2007). Einführung in das Kestenberg Movement Profile (KMP). In S Koch and S Bender (Eds.), Movement Analysis - Bewegungsanalyse. The Legacy of Laban, Bartenieff, Lamb and Kestenberg. Berlin: Logos.

Böger, C. (2011, in press). Formgenese und metaphorische Instruktion: zur Wechselwirkung von Bedeutung und Bewegung. In J Bietz \& M Roscher. (Eds.), Form und Bewegung - Prozesse der Ordnungsbildung und ihre wirklichkeitskonstituierende Bedeutung. Lehmann, Berlin.

Bordeaux Silverstein, L.; Carl F. Auerbach, C.F. \& Leacant, R.F. (2006). Using qualitative research to strengthen clinical practice. Professional Psychology: Research and Practice. 37, (4), 351-358.

Bracegirdle, C. (2007). Beauty and the Beast: Clients' experience of counselling within a narrative framework, considering concepts of containment and freedom. Unpublished doctoral thesis, submitted in partial fulfilment of the requirements of the University of Hertfordshire for the Degree Doctor of Philosophy, University of Hertfordshire Library.

Cassam, Q. (1995). Introspection and bodily self-ascription. In J Bermúdez, A Marcel \& N Eilan (Eds.), The Body and the Self (pp 311 - 336). Cambridge, Mass.: MIT.

Coffey, A. \& Atkinson P. (1996). Making sense of qualitative data: Complementary research strategies. Thousand Oaks: Sage Publications.

Coffey, A. (1999). The ethnographic self. London: Sage.

Connolly, M. \& Lathrop, A. (1997). Maurice Merleau-Ponty and Rudolf Laban - An interactive appropriation of parallels and resonances. Human Studies. 20, 27 - 45.

Csordas, T. (1993). Somatic modes of attention. Cultural Anthropology. 8 (2), 135-156.

Daly, A. (1988). Movement Analysis: Piecing together the puzzle. TDR. 32 (4), 40-52.

Damasio A. (1994). Descartes' error: Emotion, reason and human brain. London: Harper Collins Publishers, Inc.

Damasio, A. (1999). The feeling of what happens: Body and emption in the making of consciousness. London: Harcourt Inc.

Davis, M. \& Markus, K. (2006). Misleading cues, misplaced confidence: An analysis of deception detection patterns. American Journal of Dance Therapy. 28 (2), Fall/Winter, $107-126$. 
Dent-Brown, K. \& Wang, M. (2004). Pessimism and failure in 6-part stories: Indicators of borderline personality disorder? The Arts in Psychotherapy. 31 (5), 321 - 333.

Douglas, B.G. \& Moustakas, C. (1985). Heuristic inquiry: The internal search to know. Journal of Humanistic Psychology. 25 (3), 39 - 55.

Dosamantes-Alperson, E. (1982). Working with internalized relationships through a kinesthetic and kinetic imagery process. Imagination, Cognition and Personality. 2(4), 333-343.

Dulicai, D. \& Roskin Berger, M. (2005). Global dance/movement therapy growth and development. The Arts in Psychotherapy. 32 (3), 205-216.

Elfers, J. (2009). Coresearcher. Exploring human potentials. [Online] URL: http://www.coresearcher.com/ [ accessed 30th December 2009]

Ellis, R. (2001). Movement metaphor as mediator: a model for the dance/movement therapy process. The Arts in Psychotherapy. 28, $181-190$.

Elliott, M. S. \& Williams, D. I. (2001). Paradoxes of qualitative research. Counselling and Psychotherapy Research. 1 (3), 181 - 183.

Fuchs, T. (2004). The memory of the body. Unpublished Manuscript. . [Online] URL: http://www.klinikum.uni-

heidelberg.de/fileadmin/zpm/psychatrie/ppp2004/manuskript/fuchs.pdf [accessed 8th December 2008]

Fuchs, T. (2001). The tacit dimension. Philosophy, Psychiatry, \& Psychology. 8 (4), December, 323-326.

Gallagher, S. (2005). How the body shapes the mind. New York: Oxford. University Press.

Gendlin, E. (1996). Focusing-oriented psychotherapy: A manual of the experiential method. New York: Guildford Press.

Gibbs, R. W. and Bogdonovich, J. (1999). Mental Imagery in Interpreting Poetic Metaphor. Metaphor and Symbol, 14 (1), 37 - 44.

Gibbs, R.W. (2003) Embodied experience and linguistic meaning, Brain and Language. $84,1-15$.

Gibbs, R. W., Lenz, P. C. L. \& Francozo, E. (2004). Metaphor is grounded in embodied experience. Journal of Pragmatics., 36, 1189-1210.

Gorelick, K. (1989). Rapprochement between the arts and psychotherapies: metaphor the mediator. The Arts in Psychotherap., 16, 149 - 155. 
Green, J. \& Britten, N. (1998). Qualitative research and evidence based medicine. British Medical Journal. 316:1230-1232. (18 April)

Hammergren, L., Lilja, E. \& Román, G. (2007). Artists on artistic research in dance,

Danshögskolan University College of Dance. [Online]. URL: http://www.danshogskolan.se/dh/forskning_ku/close_encounters/about_artistic_researc

h.html [accessed 26th October 2007]

Hannula, M. (2004). River low, mountain high. Contextualizing artistic research. In AW Balkema \& H Slager (Eds.), Artistic Research. Amsterdam: Rodopi.

Hölter, G. (2005). Bearbeiteter Vortrag zum Jubiläumskongress der DGT Köln 16. - 18. 09. 2005.

Hunt, C. \& Samspon, F. (Eds.). (2002). The Self on the page. Theory and practice of creative writing in personal development. London: Jessica Kingsley Publishers.

Jung, C.G. (1929). Excerpt from: Alchemical Studies, Collected Works 13. In C G Jung (1997). Jung on Active Imagination. Key readings selected and introduced by Joan Chodorow. London: Routledge.

Karkou, V. \& Sanderson (2005). Arts Therapies: A Research-based map of the field. London : Churchill Livingstone.

Kaylo, J. (2004). The body in phenomenology and movement observation. E-motion. Volume XIV (7), $4-7$.

Kaylo, J. (2009). Anima and animus embodied: Junguan gender and Laban Movement Anaylsis. Body, Movement and Dance in Psychotherapy: An International Journal for Theory, Research and Practice. 1743-2987, 4 (3), 173 - 185.

Kestenberg, J. \& Sossin, K.M. (1973/1979). Developmental Patterns in Mother-Child Interaction. New.York: Dance Notation Bureau.

Kestenberg, J. (1975). Children and parents: Psychoanalytical studies in development. New York: Jason Aronson.

Kestenberg, J. S. \& Buelte, A. (1977). Prevention, infant therapy, and the treatment of adults: 2. Mutual holding and holding- oneself-up. International Journal of Psychoanalytic Psychotherapy, 6, 369-396.

Kestenberg, J. (1995). Sexuality, body movement, and the rhythms of development. New Jersey London: Jason Aronson Inc. Northvale.

Kestenberg, J., Amighi, Loman, S., Lewis, P. \& Sossin, M. (1999). The meaning of movement, developmental and clinical perspectives of the Kestenberg Movement Profile. Gordon and Breach Publishers Imprint. Overseas Publishers Association.

Kitzinger, J. (1995). Education and debate. Qualitative Research: Introducing focus groups. British Medical Journal, 311: 299-302 (29 July). 
Koch, S. (1998). The Kestenberg Movement Profile Analysis Program. Computer Software created by Nava Lotan and Eli Tziperman. American Journal of Dance Therapy. 20, 1, Spring/Summer.

Koch, S. (2006). Embodiment and creative arts therapy: From phenomenology to cognitive science. In $S$ Scoble (Ed.), European Arts Therapy. Grounding the vision to advance theory and practice. Plymouth: University Plymouth Press.

Koch, S., Cruz, R. \& Goodill, S. W. (2001). The Kestenberg Movement Profile: Performance of novice raters. American Journal of Dance Therapy. 23 (2), Fall/Winter, $71-87$.

Koltai, J. (1994). Authentic Movement: The embodied experience of text. Canadian Theatre Review. 78, 21-5.

Kövecses, Z. (2003). Metaphor and emotion. Language, Culture, and Body in Human Feeling. Cambridge: Cambridge University Press.

Lago. C. (2004). When I write I think, personal uses of writing by international students. In G Bolton et al (Eds.), Writing Cures. An introductory handbook of writing in counselling and therapy. London: Routledge.

Laban Library News, [Online]. URL:

http://www.dancenotation.org/news/Library_News/library_v2_n1.pdf [accessed 7th December 2008].

Labov, W. (1972). Language in the Inner City. Philadelphia: University of Pennsylvania Press.

Lakoff, G. and Johnson, M. (2003). Metaphors we live by. London: The University of Chicago Press.

Lakoff, G. and Johnson, M. (1999). Philosophy in the Flesh: The Embodied Mind and its Challenge to Western Thought. New York: Basic Books.

Lakoff, G. and Turner, M. (1989). More than cool reason: A field guide to poetic metaphor. Chicago: The University of Chicago Press.

Lakoff, G. (1987). Image metaphors. Metaphor and Symbol. 2 (3), 219 - 222.

Levy, F. (1988). Dance movement therapy, a healing art. Reston: American Alliance for Health, Physical Education, Recreation and Dance.

Library News, Volume II, 1, Sept 2007, p. 3. [Online]. URL: http://www.dancenotation.org/news/Library_News/library_v2_n1.pdf [accessed 27th November 2007].

McNiff, S. (1986). Freedom of research and artistic inquiry. The Arts in Psychotherapy. 13 (4), 279-284. 
McNiff, S. (1992). Art as medicine. Boston: Shambhala Books.

McNiff, S. (1993). The authority of experience. The Arts in Psychotherapy. 20, 3-9.

McNiff, S. (1998). Art-based research. London: Jessica Kingsley.

Meekums, B. (2002). Dance movement therapy. Creative therapies in practice. London: Sage Publications Ltd.

Meekums, B. \& Payne, H. (1993). Emerging methodology in dance movement therapy research. In $\mathrm{H}$ Payne (Ed.), Handbook of inquiry in the arts therapies (pp. 130 - 137). London: Jessica Kingsley.

Merleau-Ponty, M. (1962). Phenomenology of perception. London: Routledge and Kegan Paul.

Merleau-Ponty, M. (1964). The primacy of perception. C. Smith, trans. London: Routledge.

Merleau-Ponty, M. (1973). The prose of the world. Tr. by J. O'Neil . Evanston, IL: Northwestern University Press.

Miller, W. A. \& Crabtree, B. F. (2003). Clinical Research. In I N Denzin \& Y S Lincoln, (Eds.), Strategies of Qualitative Inquiry. London: Sage Publications.

Moore, C.L. \& Yamamoto (2000). Beyond words. Movement observation and analysis. London: Gordon and Breach.

Nevanlinna, T. (2004). Is artistic research a meaningful concept? In AW Balkema \& H Slager. (Eds.), Artistic Research. Amsterdam: Rodopi.

Newlove, J. \& Dalby, J. (1993). Laban for actors and dancers. Putting Laban's movement theory into practice. A step-by-step-guide. London: Nick Hern Books.

North, M. (1990). Personality assessment through movement. Plymouth: Northcote House Publishers Ltd.

Panhofer, H. (2009). New approaches to communicate the embodied experience in dance movement psychotherapy. Unpublished thesis submitted in partial fulfilment of $\mathrm{PhD}$, University of Hertfordshire, UK.

Panhofer, H., Payne, H., Meekums, B. \& Parke, T. (2011a). Dancing, moving and writing in clinical supervision? Employing embodied practices in psychotherapy supervision. The Arts in Psychotherapy, 38, 9-16.

Panhofer, H., Payne, H., Meekums, B. \& Parke, T. (2011b, in print). The space between body and mind: Two models for group supervision. In 10th ECARTE European Consortium for Arts Therapies Education. Ecarte e-publication http://www.ecarte.info/ 
Panhofer, H. (Ed.). (2005). El cuerpo en psicoterapia. La teoría y práctica de la Danza Movimiento Terapia. Barcelona: Gedisa.

Payne, H (1990). Creative movement and dance in groupwork. Oxford: Speechmark Press.

Payne, H. (1992). Shut in, shut out. In H L Payne (Ed.), Dance movement therapy: Theory and practice. London: Routledge.

Polanyi, M. (1967). The tacit dimension. Garden City, New York: Doubleday.

Rauhala, L. (2005). Ihmiskäsitys ihmistyössä (The Conception of the Human Being in Working with Humans). Helsinki: Yliopistopaino, translated by E Anttila, (2007). Mind the Body. Unearthing the Affiliation Between the Conscious Body and the Reflective Mind. In L Rouhiainen,. (Ed.) Ways of Knowing in Dance and Art. Yliopistopaino: Finnish Academy and the Arts Council of Finland.

Reason, P. and Hawkins. P. (1988). Storytelling as inquiry. In P Reason (Ed.), Human inquiry in action. (p. 79 - 101). Thousand Oaks: CA: Sage.

Richardson, L. (2000). Writing: a method of inquiry. In I Denzin \& Y Lincoln (Eds.), Handbook of Qualitative Research, 2nd edition. London: Sage:

Richardson, L. (2003). Poetic representation of interviews. In JF Gubrium \& JA Holstein. (Eds.), Postmodern Interviewing. London: Sage.

Riley, S. R. (2004). Embodied perceptual practices: Towards an embrained and embodied model of mind for use in actor training and rehearsal. Theatre Topics. 14 (2), September, 445-471.

Rossberg-Gempton, I. \& Poole, G. D. (1992). The realationship between body movement and affect: from historical and current perspectives. The Arts in Psychotherap., 19, $39-46$.

Samarritter, R. (2009). The use of metaphors in dance movement therapy. Body, Movement and Dance in Psychotherapy, 4,(1), 3 - 43.

Rycroft, C. (1995). A Critical Dictionary of Psychoanalysis. London: Penguin Books.

Sheets-Johnstone, M. (1999). The primacy of movement. Amsterdam/Philadelphia: John Benjamins.

Sheets-Johnstone, M. (2003). Kinesthetic memory. Theoria et Historia Scientiarium, Vol VII, Nr. 1. Ed Nicolas Copernicus University, 69 - 91.

Sheets-Johnstone, M. (2007). Dance, movement, and bodies: Forays into the nonlinguistic and the challenge of languaging experience: evening II. [Online]. URL: http://www.philoctetes.org/Event_Archive/Dance_Movement_and_Bodies_Forays_into the_Nonlinguistic and the_Challenge_of_Languaging_Experience_Evening_II. [accessed 26th October 2007]. 
Sheets-Johnstone, M. (2009). The corporeal turn: An interdisciplinary reader. Exeter: Imprint Academic.

Smith, M. L. (2002). Moving Self: the thread which bridges dance and theatre. Research in Dance Education. 3 (2), 123 - 141.

Somavilla, I. (2003) Aspekte philosophischer und religiöser Gewißheit bei Ludwig Wittgenstein. In Pre-Proceedings of the 26th International Wittgenstein Symposium. Austrian Ludwig Wittgenstein Society, Kirchberg am Wechsel, 331-333.

Sossin, K. M. (1987). Reliability of Kestenberg Movement Profile. Movement Studies: Observer Agreement. 2, 23-28.

Sparkes, A. C. (2002). Telling tales in sport and physical activity. A qualitative journey. Leeds: Human Kinetics.

Sparkes, A. (2003a). Bodies, identities, selves: Autoethnografic fragments and reflections. In T Denison and P Markula (Eds.), Moving Writing: Crafting movement in sport and research. New York: Peter Lang.

Sparkes, A. (2003b). Poetic representations in sport and physical education: Insider Perspectives. Sport, Education and Society, 8 (2), 153-177.

Toolan, M. (2005). Narrative, a critical linguistic introduction. $2^{\text {nd }}$ edition. London: Routledge.

Wadsworth, L. (2000). Artistic inquiry in dance/movement therapy. Creative alternatives for research. Springfield: Charles C Thomas Publisher.

Wilkins, L. E. (2002). Metaphorical language: Seeing and hearing with the heart. Journal of Poetry Therapy, 15, 3, Spring.

Willke, E., Hölter, G. \& Petzhold, H. (Eds.). (1999). Tanztherapie Theorie und Praxis. Ein Handbuch. Paderborn: Junfermannsche Verlagsbuchhdlg.

Wittgenstein, L. (1922). Tractatus Logico-Philosophicus. Frankfurt: Suhrkamp Verlag.

Wittgenstein, L. (1953). Philosophical investigations. (G.E.M. Anscombe, Trans.). New York: Maximillan.

Wolcott, H. (1994). Transforming qualitative data: description, analysis, and interpretation. London: Sage Publications.

Wolcott, H. (2001). Writing up qualitative research. London. Sage Publications. 
Appreciations to all the CoRs for their participation in the study and many thanks to Professor Helen Payne, Dr. Bonnie Meekums and Dr. Tim Parke for their support as supervisors in this project. 